\title{
PERAN PENDIDIKAN DALAM MEMBANGUN KARAKTER BANGSA YANG BERMORAL
}

\section{RIZKAN SYAHBUDIN}

\begin{abstract}
This paper is a scientific idea that aims to give an idea of the importance of building the character of moral human resources, through the internalization of positive values in the implementation of education. This is one way to be able to overcome various issues, especially moral decadence among young people. The method used is literature review. In general, the values that need to be developed and internalized in the implementation of education in Indonesia, among others, religious, mutual cooperation, togetherness, humility, refinement, hospitality, tolerance, so that the unity and unity of the nation can be realized.
\end{abstract}

Kata Kunci: Karakter Bangsa, Dekadensi Moral, Pendidikan Moral

\section{A. PENDAHULUAN}

Perlu disadari bahwa kita berada di tanah Indonesia yang dikaruniai kekayaan alam, kekayaan budaya dan jumlah penduduk yang cukup besar.Dari sinilah kita mulai melihat ke dunia luar dan bukan sebaliknya.Kita berpijak di bumi Indonesia dan kita dapat melihat ke dunia luar untuk kepentingan kita. Oleh sebab itu merupakan kewajiban kita untuk tetap menghormati dan mengembangkan nilai-nilai yang menjadi karakter bangsa Indonesia seperti gotong royong, kebersamaan, rendah hati, kehalusan budi, ramah-tamah, toleransi yang harus terus menerus dijaga dan dikembangkan untuk menjaga kesatuan bangsa Indonesia.

Demikian pula dengan tegas kita menolak nilai-nilai negatif yang lahir dari adanya perkembagan perekonomian global yang senantiasa menggiring manusia untuk lebih bersifat egois dalam arti lebih bersifat individualistik, materialistik dan berujung pada ciri kehidupan yang hedonis. Memegang teguh karakter bangsa Indonesia akan menjadikan kita bangsa yang maju, berdaulat, adil, makmur dan bermartabat. 
Berbagai masalah nasional yang dihadapi begitu kompleks dan tidak kunjung selesai.Misalnya aspek politik, di mana masalahnya mencakup kerancuan sistem ketatanegaraan dan pemerintahan, kelembagaan Negara yang tidak efektif, sistem kepartaian yang tidak mendukung, dan berkembangnya pragmatism politik.keuangan dan perbankan yang tidak memihak, dan kebijakan perdagangan dan industri yang liberal. Dan aspek sosial budaya, masalah yang terjadi saat ini adalah memudarnya rasa dan ikatan kebangsaan, disorientasi nilai keagamaan, memudarnya kohesi dan integrasi sosial, dan melemahnya mentalitas positif.

Dari sejumlah fakta positif atas modal besar yang dimiliki bangsa Indonesia, jumlah penduduk yang besar menjadi modal yang paling penting karena kemajuan dan kemunduran suatu bangsa sangat bergantung pada faktor manusianya (SDM).Masalah-masalah politik, ekonomi, dan sosial budaya juga dapat diselesaikan dengan SDM.Namun untuk menyelesaikan masalah-masalah tersebut dan menghadapi berbagai persaingan peradaban yang tinggi untuk menjadi Indonesia yang lebih maju diperlukan revitalisasi dan penguatan karakter SDM yang kuat.Salah satu aspek yang dapat dilakukan untuk mempersiapkan karakter SDM yang kuat adalah melalui pendidikan.

Pendidikan merupakan upaya yang terencana dalam proses pembimbingan dan pembelajaran bagi individu agar berkembang dan tumbuh menjadi manusia yang mandiri, bertanggungjawab, kreatif, berilmu, sehat, dan berakhlak mulia baik dilihat dari aspek jasmani maupun ruhani. Manusia yang berakhlak mulia, yang memiliki moralitas tinggi sangat dituntut untuk dibentuk atau dibangun. Bangsa Indonesia tidak hanya sekedar memancarkan kemilau pentingnya pendidikan, melainkan bagaimana bangsa Indonesia mampu merealisasikan konsep pendidikan dengan cara pembinaan, pelatihan dan pemberdayaan SDM 
Indonesia secara berkelanjutan dan merata. Ini sejalan dengan Undangundang No. 20 tahun 2003 tentang Sisdiknas yang mengatakan bahwa tujuan pendidikan adalah “.. agar menjadi manusia yang beriman dan bertakwa kepada Tuhan Yang Maha Esa, berakhlak mulia, sehat, berilmu, cakap, kreatif, mandiri, dan menjadi warga negara yang demokratis serta bertanggung jawab".

Melihat kondisi sekarang dan akan datang, ketersediaan SDM yang berkarakter merupakan kebutuhan yang amat vital. Ini dilakukan untuk mempersiapkan tantangan global dan daya saing bangsa.Memang tidak mudah untuk menghasilkan SDM yang tertuang dalam UU tersebut.Persoalannya adalah hingga saat ini SDM Indonesia masih belum mencerminkan cita-cita pendidikan yang diharapkan.Misalnya untuk kasus-kasus aktual, masih banyak ditemukan siswa yang menyontek di kala sedang menghadapi ujian, bersikap malas, tawuran antar sesama siswa, melakukan pergaulan bebas, terlibat narkoba, dan lain-lain. Di sisi lain, ditemukan guru, pendidik yang senantiasa memberikan contohcontoh tidak baik ke siswanya. Kondisi ini terus terang sangat memilukan dan mengkhawatirkan bagi bangsa Indonesia yang telah merdeka sejak tahun 1945.

Kondisi ini mencerminkan masalah moral yang memainkan peran cukup sgnifikan yang mengharuskan adanya tindakan-tindakan untuk mengatasinya. Jawaban yang paling kompleks yaitu melalui pendidikan baik formal, informal maupun non formal, sebagai upaya untuk membangun karakter SDM yang bermoral sehingga mampu membentuk pribadi yang kuat dan tangguh dalam menghadapi persaingan yang semakin ketat dimasa yang akan datang. 


\section{B. PEMBAHASAN}

1. Pengaruh Globalisasi terhadap Perkembangan moral PESERTA DIDIK.

Perkembangan Teknologi dan Informasi merupakan factor pendukung utama arus globalisasi.Perkembangan teknologi dewasa ini begitu cepat sehingga segala informasi dengan berbagai bentuk dapat tersebar luas ke seluruh dunia.Oleh karena itu globalisasi tidak dapat kita hindari kehadirannya.Akibat globalisasi tentunya membawa pengaruh terhadap suatu negara termasuk Indonesia, khususnya terhadap perkembangan moral peserta didik.

Pengaruh negatif globalisasi yang berkaitan dengan perkembangan moral peserta didik antara lain dalam bidang budaya dan sosial, banyak dikalangan remaja telah hilang nilai-nilai nasionalisme bangsa kita, misalnya sudah tidak kenal sopan santun, cara berpakaian, dan gaya hidup mereka cenderung meniru budaya barat. Munculnya sikap individualisme, kurang peduli terhadap orang lain sehingga sikap gotong royong semakin luntur. Oleh karena itu, perlu dilakukan langkah-langkah untuk mengantisipasi pengaruh negatif arus globalisasi terhadap nilai-nilai nasionalisme bangsa kita, khususnya terhadap perkembangan moral peserta didik. Langkahlangkah untuk mengantisipasi pengaruh negatif arus globalisasi perkembangan moral peserta didik antara lain:

1. Menanamkan sikap kepada peserta didik untuk mencintai produk dalam negeri melalui pembelajaran di sekolah

2. Menumbuhkembangkan nilai-nilai Pancasila yang merupakan dasar negara kita terhadap peserta didik

3. Menanamkan dan melaksanakan ajaran agama tidak hanya tanggung jawab guru agama, melainkan merupakan tanggung jawab oleh semua guru bidang studi 
4. Menginformasikan kepada peserta didik untuk menyeleksi arus globalisasi dalam segala bidang, melalui pembelajaran.

Dengan cara mengantisipasi pengaruh negatif arus globalisasi terhadap perkembangan moral peserta didik, maka diharapkan peserta didik nantinya akan terhindar dari budaya barat yang tidak relevan dengan nilai-nilai nasionalisme dan cita-cita luhur bangsa kita yang telah digariskan dalam Undang-Undang Negara Republik Indonesia.

2. Membangun Sumber daya Manusia Berkarakter di ERA GLobalisasi

SDM merupakan aset paling penting untuk membangun bangsa yang lebih baik dan maju.Namun untuk mencapai itu, SDM yang kita miliki harus berkarakter. SDM yang berkarakter kuat dicirikan oleh kapasitas mental yang berbeda dengan orang lain seperti keterpercayaan, ketulusan, kejujuran, keberanian, ketegasan, ketegaran, kekuatan dalam memegang prinsip, dan sifat-sifat unik lainnya yang melekat dalam dirinya.

Secara lebih rinci, beberapa konsep tentang manusia Indonesia yang berkarakter dan senantiasa melekat dengan kepribadian bangsa. Ciri-ciri karakter SDM yang kuat meliputi (1) religious, yaitu memiliki sikap hidup dan kepribadian yang taat beribadah, jujur, terpercaya, dermawan, saling tolong menolong, dan toleran; (2) moderat, yaitu memiliki sikap hidup yang tidak radikal dan tercermin dalam kepribadian yang tengahan antara individu dan sosial, berorientasi materi dan ruhani serta mampu hidup dan kerjasama dalam kemajemukan; (3) cerdas, yaitu memiliki sikap hidup dan kepribadian yang rasional, cinta ilmu, terbuka, dan berpikiran maju; dan (4) mandiri, yaitu memiliki sikap hidup dan kepribadian merdeka, disiplin tinggi, hemat, menghargai waktu, ulet, wirausaha, kerja keras, dan 
memiliki cinta kebangsaan yang tinggi tanpa kehilangan orientasi nilainilai kemanusiaan universal dan hubungan antarperadaban bangsabangsa (PP Muhammadiyah, 2009).

Tidak dapat dipungkiri, arus globalisasi begitu cepat merasuk ke dalam masyarakat terutama di kalangan remaja.Pengaruh globalisasi terhadap anak muda begitu kuat.Pengaruh globalisasi tersebut telah membuat banyak anak muda kita kehilangan kepribadian diri sebagai bangsa Indonesia. Hal ini ditunjukkan dalam kehidupan sehari-hari, misalnya dalam cara berpakaian, selera makan. Yang lebih memprihatinkan adalah pergaulan bebas antar remaja.

Pada Era globalisasi dewasa ini dekadensi moral tidak hanya terjadi di kalangan remaja saja, namun banyak terjadi pula dikalangan orang dewasa.Hal ini tidak bisa kita pungkiri lagi, ternyata di negeri tercinta yang berdasarkan Pancasila ini telah menodai nilainilai luhur dari Pancasila itu sendiri. Hal ini terbukti semakin maraknya korupsi oleh para pemimpin bangsa ini mulia dari level yang rendah sampai pada level yang tinggi.

Oleh karena itu, satu hal yang perlu untuk dipahami bahwa karakter tidak dapat dilepaskan dari konteks sosial budaya karena karakter terbentuk dalam lingkungan sosial budaya tertentu.Dalam hal ini para guru di sekolah dan orang tua harus saling mengisi untuk menumbuhkan karakter positip pada anak melalui pembelajaran yang berkaitan dengan pendidikan agama sehingga generasi mendatang bangsa kita menjadi bangsa yang beriman berbudi pekerti luhur, berakhlak mulia.

\section{PERAN PENDidik dAlam MeMBentuk KaraKter SDM}

Pendidik itu bisa guru, orangtua atau siapa saja, yang penting ia memiliki kepentingan untuk membentuk pribadi peserta didik atau anak. Peran pendidik pada intinya adalah sebagai masyarakat yang 
belajar dan bermoral. Lickona, Schaps, dan Lewis (2007) serta Azra (2006) menguraikan beberapa pemikiran tentang peran pendidik, di antaranya:

1. Pendidik perlu terlibat dalam proses pembelajaran, diskusi, dan mengambil inisiatif sebagai upaya membangun pendidikan karakter

2. Pendidik bertanggungjawab untuk menjadi model yang memiliki nilai-nilai moral dan memanfaatkan kesempatan untuk mempengaruhi siswa-siswanya. Artinya pendidik di lingkungan sekolah hendaklah mampu menjadi "uswah hasanah" yang hidup bagi setiap peserta didik.Mereka juga harus terbuka dan siap untuk mendiskusikan dengan peserta didik tentang berbagai nilainilai yang baik tersebut.

3. Pendidik perlu memberikan pemahaman bahwa karakter siswa tumbuh melalui kerjasama dan berpartisipasi dalam mengambil keputusan

4. Pendidik perlu melakukan refleksi atas masalah moral berupa pertanyaanpertanyaan rutin untuk memastikan bahwa siswasiswanya mengalami perkembangan karakter.

5. Pendidik perlu menjelaskan atau mengklarifikasikan kepada peserta didik secara terus menerus tentang berbagai nilai yang baik dan yang buruk.

Berdasarkan penjelasan di atas, maka peran pendidik di setiap jenis lembaga pendidikan dalam membentuk karakter siswa. Dalam pendidikan formal dan non formal, pendidik (1) harus terlibat dalam proses pembelajaran, yaitu melakukan interaksi dengan siswa dalam mendiskusikan materi pembelajaran, (2) harus menjadi contoh tauladan kepada siswanya dalam berprilaku dan bercakap, (3) harus mampu 
mendorong siswa aktif dalam pembelajaran melalui penggunaan metode pembelajaran yang variatif, (4) harus mampu mendorong dan membuat perubahan sehingga kepribadian, kemampuan dan keinginan guru dapat menciptakan hubungan yang saling menghormati dan bersahabat dengan siswanya, (5) harus mampu membantu dan mengembangkan emosi dan kepekaan sosial siswa agar siswa menjadi lebih bertakwa, menghargai ciptaan lain, mengembangkan keindahan dan belajar soft skills yang berguna bagi kehidupan siswa selanjutnya, dan (6) harus menunjukkan rasa kecintaan kepada siswa sehingga guru dalam membimbing siswa yang sulit tidak mudah putus asa.

Sementara dalam pendidikan informal seperti keluarga dan lingkungan, pendidik atau orangtua/tokoh masyarakat (1) harus menunjukkan nilai-nilai moralitas bagi anakanaknya, (2) harus memiliki kedekatan emosional kepada anak dengan menunjukkan rasa kasih sayang, (3) harus memberikan lingkungan atau suasana yang kondusif bagi pengembangan karakter anak, dan (4) perlu mengajak anak-anaknya untuk senantiasa mendekatkan diri kepada Allah, misalnya dengan beribadah secara rutin. Berangkat dari upaya-upaya yang pendidik lakukan, maka diharapkan akan tumbuh dan berkembang SDM yang berkarakter dan bermoral yang memiliki kemampuan unggul dalam menghadapi globalisasi.

\section{KESIMPULAN}

Untuk menjadi bangsa yang maju dan bermartabat ditengah perkembangan perekonomian global yang sangat pesat sangatlah tergantung pada faktor manusianya atau kualitas sumber daya manusia (SDM) yang dimiliki bangsa Indonesia. Oleh karena itu, salah satu cara untuk bisa mengatasi berbagai persoalan yang terjadi baik persoalan 
politik, ekonomi, dan social, budaya serta masalah dekadensi moral khususnya dikalangan para pelajar, maka dibutuhkan penguatan karakter SDM yang kuat yang didasarkan pada karakter bangsa indonesia melalui berbagai jenis pendidikan (formal, informal dan non formal) serta pada berbagai jenjang pendidikan (mulai dari pendidikan dasar, menengah, dan perpendidikan tinggi).

Penulis : Drs. H. Rizkan Syahbudin, M.Pd (rizkansyahbudin89 @gmail.com) Dosen Fakultas Tarbiyah dan Tadris IAIN Bengkulu.

\section{DAFTAR PUSTAKA}

Asri, B, (2008). Pembelajaran Moral. Jakarta: PT Rineka Cipta

Darmiyati, Tri. Pengaruh Globalisasi terhadap Nilai-Nilai Nasionalisme. http:/ / www.wikimu.com/News/DisplayN ews.aspx?id=7124;

Edi Subkhan, mahasiswa Program Pascasarjana, S2 Universitas Negeri Jakarta dalam http://edukasi.kompasiana.com/2010/05/ 23/mari-membangun-karakter-bangsamelalui-olah-pikir-olahhati-olah-ragaolah-rasa-dan-karsa;

Hamid, M, (2008). Peran serta Guru Profesional dalam Turut Membentuk karakter bangsa Melalui Jalur Pendidikan Nonformal dan Informal. Jakarta: disajikan dalam Seminar nasional;

Lickona, Tom; Schaps, Eric, dan Lewis, Catherine (2007).Eleven Principles of Effective Character Education. Character Education Partnership;

Munir, (2010). Pendidikan Karakter. Yogyakarta: PT Pustaka Insan Maqdani, Anggota IKPI; 
Pimpinan Pusat Muhammadiyah (2009). Revitalisasi Visi dan Karakter Bangsa. Yogyakarta: PP Muhammadiyah;

Wardani. 2008. Pendidikan sebagai Wahana Pembentukan Karakter Bangsa. Jakarta: disajikan dalam Seminar nasional;

Wardoyo, Cipto.2007. Urgensi Pendidikan Moral pada (http://www.nu.or.id 